\title{
Use of the API-ZYM system in rapid identification of $\alpha$ and non-haemolytic streptococci
}

\author{
SHEENA A WAITKINS, LYN C BALL, AND CHERRY AM FRASER \\ From the Division of Hospital Infection, Central Public Health Laboratory, Colindale Avenue, London \\ NW9 $5 H T, U K$
}

SUMMARY The API-ZYM method of detecting enzymes was tested using 99 streptococci isolated from clinical material and 14 type species obtained from the National Collection of Type Cultures. We found the method easy and reliable. The results obtained indicate that this method could be a useful identification system in busy routine clinical laboratories.

The streptococci commonly known as the 'indifferent' streptococci, that is, those belonging to the 'viridans' group and the non-haemolytic organisms, include a number of species that differ greatly in their ability to cause specific diseases in man. Streptococcus bovis, ${ }^{1}$ Streptococcus mitior, and Streptococcus sanguis are all associated with endocarditis, ${ }^{1}$ while deep-seated abscesses often yield Streptococcus milleri. ${ }^{1,2,3}$ These species can be identified by a whole battery of cultural and serological tests. ${ }^{4}$ However, the tests as they are currently performed are slow, tedious, and time-consuming as well as utilising highly complex media. All of these factors combined occasionally lead to equivocal results being recorded. Because of this unreliability, it may be difficult to identify and subsequently classify the streptococci isolated from man, and these are most often dismissed with the general term 'viridans streptococci'.

Supplementary, or even entirely new, alternative means of identification are required. Such a new system has been successfully developed to detect rapidly specific enzymes from single substrates using a heavy inoculum of organisms or biological fluid. ${ }^{5}$ This Auxotab system has been sucessfully applied in both animal tissues, ${ }^{6}$ and biological fluids. ${ }^{7,8}$ Both staphylococci ${ }^{9}$ and Erwinia ${ }^{10}$ have been identified using the above system. Recently, it has been modified into a commercially packaged system called API-ZYM (API Laboratory Products Ltd, Farnborough), utilising 19 substrates from which enzymes can be detected within 4 hours. Using this modified enzyme detection system, anaerobic ${ }^{11}$ and aerobic bacteria, including a few streptococci, ${ }^{12}$ have been identified.

This paper presents, in full, our initial results

Received for publication 9 July 1979 which were reported at the Second International Symposium on Rapid Methods, Cambridge, England, in 1976. ${ }^{13}$

\section{Material and methods}

ORGANISMS

The following type strains were obtained from the National Collection of Type Cultures, Colindale, London. Strep. faecalis (NCTC 775, 2705, 5957); Strep. durans (NCTC 8174); Strep. faecium (NCTC 7380, 7366, 7176, 7182, 7379); Strep. equinus (NCTC 10389); Strep. milleri (NCTC 10708, 10709); Strep. mutans (NCTC 10449); and Strep. sanguis (NCTC 7864).

The remaining streptococci studied were those routinely sent to the Streptococcus Reference Laboratory for identification using the methods described by Parker and Ball. ${ }^{1}$ The identity and numbers of streptococci used to test the API-ZYM system are shown in Table 1.

\section{CULTURAL METHODS}

The organisms to be tested were first grown on $5 \%$ horse blood agar to ensure purity of culture. Then a sweep inoculation was made into Todd Hewitt Broth, and this was incubated overnight at $37^{\circ} \mathrm{C}$. After incubation the broths were centrifuged at $2000 \mathrm{rpm}$ for 15 minutes, and the deposit was washed three times with physiological saline, before they were finally resuspended in saline to give approximately $10^{6} \mathrm{cfu} / \mathrm{ml}$. This suspension was used to inoculate the API-ZYM system.

\section{IDENTIFICATION PROCEDURE}

The API-ZYM system consists of a plastic gallery containing 20 cupules; 19 of these have substrates 
Table 1 Identity and number of streptococci used to test the API-ZYM system

\begin{tabular}{|c|c|c|}
\hline & No. tested (including NCTC strains) \\
\hline $\begin{array}{l}\text { Strep.faecalis } \\
\text { Strep.durans } \\
\text { Strep.faecium } \\
\text { Strep.equinus } \\
\text { Strep.bovis } \\
\text { Strep.milleri } \\
\text { Strep.mutans } \\
\text { Strep.mitior Dex }- \\
\text { Strep.mitior Dex }+ \\
\text { Strep.sanguis Dex }+ \text {, } \\
\text { Aesc }+, \text { Arg }+ \\
\text { Strep.sanguis Dex }+ \text {, } \\
\text { Aesc -, Arg }+ \\
\text { Strep.sanguis } \\
\text { Miscellaneous } \\
\text { Tota l }\end{array}$ & $\begin{array}{l} \\
(8) \\
(6) \\
(4) \\
(7) \\
(6)\end{array}$ & $\begin{array}{r}21 \\
4 \\
10 \\
3 \\
18 \\
17 \\
9 \\
14\end{array}$ \\
\hline
\end{tabular}

and buffer impregnated into inert supportive fabric, while cupule No. 1 contains no substrate and acts as a negative control. The substrates detect those enzymes listed in Table 2. Two drops of $0.02 \mathrm{ml}$ prepared bacterial suspension were dropped into each cupule, and the gallery was fitted into a chamber previously moistened with distilled water. This was then incubated aerobically at $37^{\circ} \mathrm{C}$ for 4 hours. After incubation $0.04 \mathrm{ml}$ of the API reagents $A$ and $B$ were added to each cupule and exposed for 30 seconds to a very strong light source (1000 Watt lamp). The resulting colours were recorded as intensities and could be read to give a semiquantitative notation ( 0 to 5 ) using a colour code supplied by the manufacturers. Each strain was tested at least twice with the API-ZYM to ensure reproducibility of results.

\section{Results}

The results of the API-ZYM system are summarised in Table 3. This presents all the reactions produced by the streptococci tested. From it emerges a distinct pattern of enzyme production which serves to differentiate the various strains. The colour intensity of 'key' reactions is reserved for those that attain a score of 3 or more on the colour chart provided. It can be seen that certain substrates are never metabolised, that is, 17 and 20 (see Table 2), while others are rarely utilised $(5,9,13,14,15$, and 19). Indeed, these substrates are totally redundant with regard to final identification, which is based on the remaining 11. Conversely, substrate 6 (leucine aminopeptidase) is always metabolised by streptococci and must surely form a 'key' test for this group of organisms. No other substrate provides such exclusive characterisation, with the exception of Strep. mitior Dextran + which alone uses substrate 18 (glucosaminidase).

The results presented in Table 3 also support the established biochemical divisions of certain controversial streptococci. For example, Strep. mitior can be divided into those organisms that produce dextran in sucrose broth or those that do not. The latter is typical of the classical Strep. mitior, while the former, although adhering to the other biochemical criteria, does produce dextran and is designated Strep. mitior Dextran +.4 These two biochemically different organisms, Strep. mitior Dextran - and Strep. mitior Dextran + , can be recognised in the API-ZYM system; Strep. mitior Dextran - utilises substrates $6,7,8,11$, and 12 while Strep. mitior Dextran + utilises 2, 3, 6, 7, 8, 11, 12, and, uniquely, 18. Similarly, the classical biochemical divisions that exist between Strep. sanguis Aesculin -, Arginine hydrolysis +, and Dextran + (type specific strain) and Strep. sanguis Aesculin -, Arginine hydrolysis + , and Dextran $+^{1}$ are reinforced by the API-ZYM system (metabolism of substrates $2,3,6,7,8$, and 11 and $2,3,6,7,8,11,12$, and 16 , respectively). However, the miscellaneous Strep. sanguis that do not strictly adhere to formal classification exhibit the same confusion even when the API-ZYM system is used.

Finally, Table 3 emphasised two important findings: firstly, that Strep. mitior, normally a very unreactıve organism biochemically, metabolises such a vast array of substrates in the API-ZYM system; secondly, Strep. milleri, while providing the

Table 2 Enzymes detected by the API-ZYM test

\begin{tabular}{llll}
\hline Test & Enzyme assayed for: & Test & Enzyme assayed for: \\
\hline 1 & Control & 11 & Phosphatase acid \\
2 & Phosphatase alkaline & 12 & Phosphoamidase \\
3 & Esterase (C 4) & 13 & a Galactosidase \\
4 & Esterase lipase (C 8) & 14 & $\beta$ Galactosidase \\
5 & Lipase (C 14) & 15 & B Glucuronidase \\
6 & Leucine aminopeptidase & 16 & a Glucosidase \\
7 & Valine aminopeptidase & 17 & $\beta$ Glucosidase \\
8 & Cystine aminopeptidase & 18 & B Glucosaminidase \\
9 & Trypsin & 19 & a Mannosidase \\
10 & Chymotrypsin & 20 & a Fucosidase \\
\hline
\end{tabular}


Table 3 Reaction of type strains with API-ZYM

\begin{tabular}{|c|c|c|c|c|c|c|c|c|c|c|c|c|c|c|c|c|c|c|c|c|c|}
\hline \multirow[t]{2}{*}{ Organism } & \multirow[t]{2}{*}{ No. } & \multicolumn{20}{|c|}{$A P I-Z Y M N o}$. \\
\hline & & 1 & 2 & 3 & 4 & 5 & 6 & 7 & 8 & 9 & 10 & 11 & 12 & 13 & 14 & 15 & 16 & 17 & 18 & 19 & 20 \\
\hline \multirow[t]{3}{*}{ Strep.faecalis } & 21 & - & ${ }^{*} 0_{1}$ & ${ }_{2}^{19}$ & ${ }^{21}$ & 0 & ${ }^{21}$ & 0 & 19 & 0 & 0 & 20 & 210 & 0 & 0 & 0 & 21 & 0 & 0 & 0 & 0 \\
\hline & & & 0 & $4^{2}$ & 4 & 0 & 4 & & & & & & 4 & & $\mathbf{v}$ & 0 & & 0 & 1 & 0 & 0 \\
\hline & 4 & - & 1 & 0 & 0 & $\mathbf{0}$ & 0 & 0 & 0 & 0 & 0 & 0 & 0 & 0 & 0 & 0 & 0 & 0 & 0 & 0 & $\mathbf{0}$ \\
\hline \multirow{2}{*}{ Strep.faecium } & & & & 10 & 10 & & 10 & & & 0 & 10 & & & & 0 & & & & & & \\
\hline & 10 & 一 & 0 & 0 & 0 & 0 & $3^{0}$ & $3^{0}$ & 2 & 1 & $\mathbf{0}$ & $2^{0}$ & 0 & 0 & 1 & 0 & 0 & 0 & $\mathbf{0}$ & 0 & 0 \\
\hline Strep.equinus & 3 & - & 0 & 0 & 0 & 0 & o & 0 & 0 & 0 & 0 & 0 & 0 & 0 & 0 & 0 & 0 & 0 & 0 & 0 & 0 \\
\hline \multirow[t]{2}{*}{ Strep.bovis } & & & 18 & 18 & & & 18 & 0 & 17 & & 0 & & & 0 & 0 & & 17 & & 0 & & \\
\hline & 18 & - & 0 & 0 & 0 & $\mathbf{0}$ & 0 & 2 & 1 & 0 & 4 & 0 & 0 & 3 & 1 & 0 & 0 & 0 & 1 & 0 & $\mathbf{0}$ \\
\hline \multirow[t]{2}{*}{ Strep.milleri } & & 一 & 17 & 16 & & & 17 & 17 & 17 & & & 16 & 0 & 0 & & & 8 & & & & \\
\hline & 17 & - & 0 & 1 & 0 & 0 & 0 & 0 & 0 & 0 & 0 & 1 & 1 & 3 & 0 & 0 & 1 & 0 & 0 & 0 & 0 \\
\hline \multirow{2}{*}{ Strep.mutans } & & & 8 & 6 & 8 & 1 & 7 & 1 & & & 3 & 7 & 0 & & 1 & & 0 & & 1 & & \\
\hline & 9 & - & & & 1 & 10 & $8^{0}$ & $8^{2}$ & $8^{0}$ & 0 & $1^{2}$ & $8^{0}$ & $8^{2}$ & 0 & 1 & $2^{0}$ & $2^{5}$ & 0 & 0 & 0 & 0 \\
\hline Strep.mitior Dex - & 8 & - & 3 & 0 & 0 & 0 & 1 & 0 & 0 & 0 & 0 & 0 & 0 & 0 & 0 & 0 & 0 & 0 & 0 & 0 & 0 \\
\hline \multirow[t]{2}{*}{ Strep.mitior Dex + } & & & 5 & 6 & & 1 & 5 & 6 & 6 & & 1 & 6 & 3 & 1 & 1 & 2 & 2 & & 6 & & \\
\hline & 6 & - & 0 & 0 & 0 & 0 & 0 & 0 & 0 & 0 & 0 & 0 & 0 & 0 & 0 & 0 & 0 & 0 & 0 & 0 & 0 \\
\hline Strep.sanguis Dex + , & & & 4 & 4 & & & 4 & 4 & 4 & & & 4 & & 0 & & & & & & & \\
\hline $\begin{array}{l}\text { Aesc }+, \text { Arg }+ \\
\text { Strep. sanguis Dex }+\end{array}$ & 4 & - & 0 & 0 & 0 & 0 & 0 & 0 & 0 & 0 & 0 & 0 & 0 & 1 & 0 & 0 & 0 & 0 & 0 & 0 & 0 \\
\hline $\begin{array}{l}\text { Strep.sanguis Dex +, } \\
\text { Aesc - , Arg + }\end{array}$ & 7 & - & ${ }_{0}^{7}$ & ${ }^{7} 0$ & $1_{2}$ & 0 & ${ }^{7}$ & ${ }^{6}$ & ${ }^{7}$ & 0 & ${ }_{0}^{1}$ & ${ }^{7}$ & ${ }^{7}$ & $0_{3}$ & 0 & $1_{0}$ & ${ }^{7}$ & & & & 0 \\
\hline Strep.sanguis Miscellaneous & & & 5 & 3 & 3 & & 5 & 3 & 4 & & 5 & 5 & 3 & 2 & 1 & 1 & 5 & & 1 & 2 & 0 \\
\hline & 6 & - & $\mathbf{0}$ & 0 & 0 & 0 & $\mathbf{0}$ & 0 & 0 & 0 & 0 & 0 & 0 & 0 & 0 & 0 & 0 & 0 & 0 & 0 & 0 \\
\hline
\end{tabular}

*The first figure is the number of isolates with strong activity (3-5), the second number with weak activity (1-2).

0 alone indicates a completely negative reaction.

Table 4 Summary of API-ZYM results

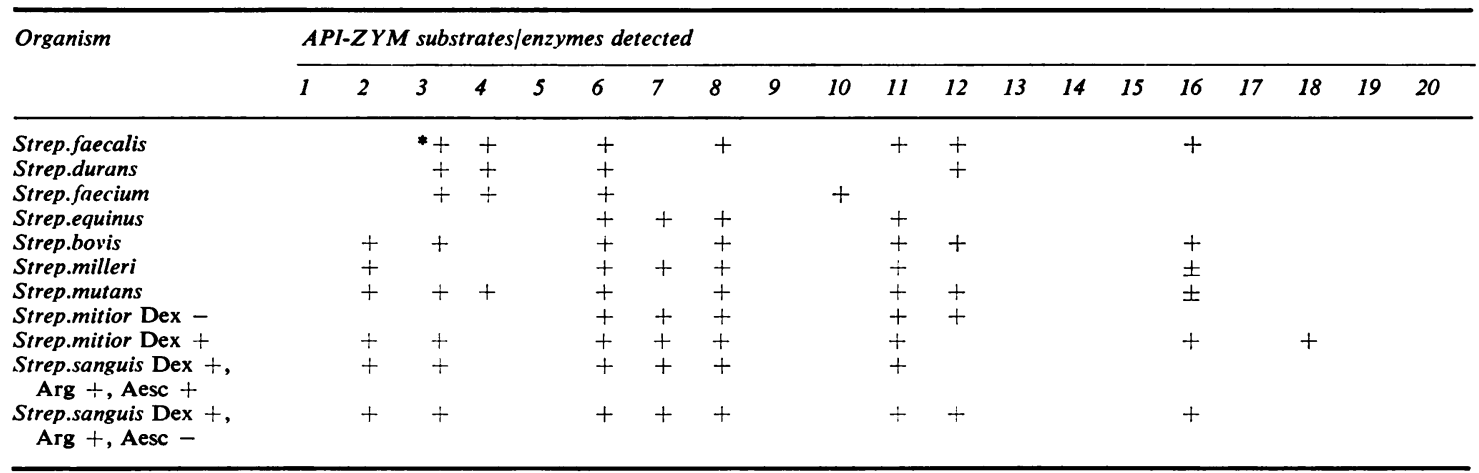

*Positive colour, intensity $3 \rightarrow 5$ on API-ZYM colour code.

\pm Half the numbers tested gave a positive reaction.

'key' reactions of $2,6,7,8$, and 11 , also metabolises substrate 16 (glucosidase) in over half the numbers tested (9/17).

These reactions can be more clearly seen in Table 4, which presents the 'key' reactions as a code for each individual strain of streptococci investigated. A 'key' reaction is one that reacts strongly in the system (colour intensity 3 or greater) consistently with all strains tested. The code for each organism is then arranged using these 'key' reactions, as in Table 4.

If the code is strictly used, a high percentage of correct identification can be achieved (Table 5). Not surprisingly, those organisms that have a welldefined, conventional, biochemical classification identify most easily and most often using the APIZYM, for example, Strep. faecalis $(90 \%$ correct identification) and Strep. faecium $(100 \%$ correct identification), while other streptococci reflect the 
Table 5 Percentage of correct identification using API-ZYM code

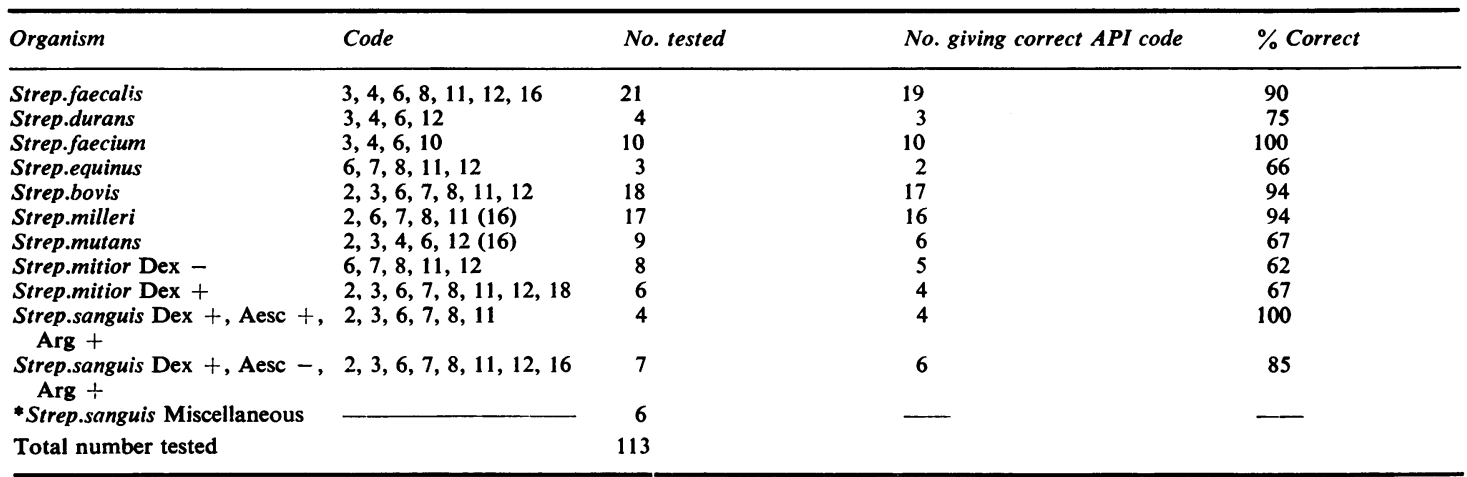

(16) Half of these organisms gave positive reactions.

*See text.

uncertainty of their biochemical biotypes with similar uncertain identification in the system, for example, Strep. mitior and Strep. sanguis.

\section{Discussion}

The results of this study indicate quite clearly that the API-ZYM system could be used as a simple, rapid, and reliable method to identify streptococci. The method is most useful when used on wellcharacterised strains such as the group D streptococci, where correct identification, as compared to the classical biochemical patterns, approximates nearly $\mathbf{9 0 - 9 5 \%}$ accuracy. However, even the other less well-identified organisms, such as Strep. mitior Dextran +, give fairly respectable identification rates of $67 \%$. This reflects a considerable saving in laboratory time, particularly when the API-ZYM method can be read with only 4 hours' incubation compared to periods of five days when using conventional biochemical methods. One of the most important viridans streptococci today is Strep. milleri. This organism has been established as a major cause of deep-seated abscesses and systemic infections by both Parker and Ball ${ }^{1}$ and Poole and Wilson. ${ }^{3,4}$ Identification using conventional methods is, as pointed out above, long and tedious. APIZYM affords a quick and reliable method to identify the organism and thereby alert the clinician of the patient's potentially serious infection. It is interesting to note that approximately half of the Strep. milleri tested produced the enzyme $\alpha$ glucosidase. Whether this finding is significant would have to be investigated further.

In a previous study ${ }^{14}$ we showed that viridans streptococci could be adequately identified in the routine laboratory using a variety of simple bio- chemical reactions. In the present one, the use of API-ZYM facilitates a quicker and easier method to achieve the same identification. But, even with this method, there are occasions when a more complete classification of the organism must be undertaken. When this occurs the full biochemical methods described by Waitkins et al. ${ }^{14}$ would have to be used.

However, in the main we found that API-ZYM in our hands gave good, reliable, and accurate identification of potentially harmful streptococci. It would certainly enable the busy routine laboratory to pursue these organisms and achieve correct identification in at least $60 \%$, and sometimes even $100 \%$, of all streptococci investigated.

We thank API Laboratory Products Ltd for supplies of the API-ZYM strips.

\section{References}

${ }^{1}$ Parker M T, Ball L C. Streptococci and aerococci associated with systemic infection in man. $J \mathbf{M e d}$ Microbiol 1976; 9: 275-302.

${ }^{2}$ Poole P M, Wilson G. Infection with minute-colonyforming beta-haemolytic streptococci. J Clin Pathol 1976; 29 : 740-745.

${ }^{3}$ Poole P M, Wilson G. Streptococcus milleri in the appendix. J Clin Pathol 1977; 30: 937-942.

${ }^{4}$ Colman G, Williams R E O. Taxonomy of some human viridans streptococci. In: Wannamaker $\mathbf{L} \mathbf{W}$, Matsen J M, eds. Streptococci and Streptococcal Diseases: Recognition, Understanding and Management. New York and London: Academic Press, 1972: 281-299.

${ }^{5}$ Bussière J, Fourcard A, Colobert L. Usage de substrates synthétiques pour l'étude de l'équipe.nent 
enzymatique de microorganismes. $C R$ Acad Sci (D) (Paris) 1967; 264: 415-417.

${ }^{6}$ Plantevin G, Mardon P. Utilisation d'une microméthode de detection (auxotab) pour la recherche qualitative d'activités enzymatiques dans les tissues d'insectes. Tube digestif. Ann Zool Ecol Animal 1972; 2: 229-248.

${ }^{7}$ Menezo Y, Fléchon J E. Utilisation d'une microtechnique pour la determination des activités enzymatiques des spermatozoïdes et du plasma seminal chez le lapin et le taureau. C R Acad Sci (D) (Paris) 1973; 277: 1037-1040.

${ }^{8}$ Menezo Y, Testart J. Étude du sérum sanguin et du liquide foliculaire préovulatoire chez la vache. Ann Biol Anim Biochim Biophys 1975; 15 : 1-8.

${ }^{9}$ Joubert L, Buissière J. Les chimiotypes épidemiologiques des staphylocoques animaux. Société de Science Vétérinaire et de Médecine Comparée 1968; 70: 317-336.

${ }^{10}$ Peny J. Caractère biochimique des Erwiniae. Position par rapport aux genres taxonomiques Enterobacter et Pectobacterium. Report from the Conference on the
Taxonomy of Bacteria, University BRNO, Czechoslovakia, in SPIS Y, 1970; 1-6: 37-43.

${ }^{11}$ Tharagonnet D, Sisson P R, Roxby C M, Ingham $H$ R, Selkon J B. The API-ZYM system in the identification of gram-negative anaerobes. J Clin Pathol 1977; 30: 505-509.

${ }^{12}$ Humble $M$ W, King A, Phillips I. API-ZYM: A simple rapid system for the detection of bacterial enzymes. J Clin Pathol 1977; 30: 275-277.

${ }^{13}$ Waitkins S A, Ball L C, Fraser C A M. Identification of streptococci using the API-ZYM system. 2nd International Symposium on Rapid Methods and Automation in Microbiology, Cambridge, England, 19-25 September 1976. 1978: 67-68.

${ }^{14}$ Waitkins S A, Ball L C, Fraser C A M. A shortened scheme for the identification of indifferent streptococci. J Clin Pathol 1980; 33. In press.

Requests for reprints to: Dr SA Waitkins, Regional Public Health Laboratory, Fazakerley Hospital, Lower Lane, Liverpool L9 7AL, UK. 